\title{
PELATIHAN BERBASIS FIRST PRINCIPLES OF INSTRUCTION BAGI GURU BK MADRASAH DI GARUT
}

\author{
APIP PIRMANSYAH \\ MAN 1 Garut Jawa Barat \\ Email : apippirmans@gmail.com
}

\begin{abstract}
ABSTRAK
Penelitian bertujuan untuk menguji efektivitas program pelatihan kompetensi guru bimbingan dan konseling berbasis First Principles of Instruction. Penelitian menggunakan pendekatan kuantitatif, dengan metode quase experiment dan desain one-group pretest-posttest. Instrumen yang digunakan berupa tes kompetensi berbentuk pilihan ganda yang terdiri atas 40 soal. Subjek penelitian sebanyak 25 guru bimbingan dan konseling madrasah di Kabupaten Garut dengan teknik analisis data menggunakan Uji Wilcoxon. Hasil penelitian menunjukkan bahwa: Pertama, Kompetensi guru bimbingan dan konseling madrasah di Kabupaten Garut berada pada kategori sedang dengan rata-rata skor 53,78. Kedua, Program Pelatihan berbasis First Principles of Instruction terbukti efektif dalam meningkatkan kompetensi guru bimbingan dan konseling madrasah di Kabupaten Garut.
\end{abstract}

Kata Kunci: Pelatihan, First Principles of Instruction, Kompetensi Guru Bimbingan dan Konseling

\section{PENDAHULUAN}

Peningkatan kompetensi bagi individu agar dapat bekerja dengan profesional masih menjadi isu yang cukup menarik (Arman, 2018). Hal ini disebabkan karena kompetensi memiliki pengaruh terhadap kinerja (Saputra, 2016; Manik \& Syafrina, 2018; Sriwidodo \& Haryanto, 2010; Setiawati, 2009). Apabila guru memiliki kompetensi yang baik maka sangat mungkin ia memiliki kinerja yang baik dalam menjalankan pekerjaannya. Oleh karena itu, setiap guru termasuk guru bk harus memiliki kompetensi dalam melaksanakan tugas-tugas keprofesionalannya (UU Nomor 14 Tahun 2005).

Pentingnya kompetensi bagi guru bk juga menjadi perhatian ASCA National Model (2012) yang membagi kegiatan bimbingan menjadi empat bidang yaitu bidang: 1) foundation yang berisi pemikiran, filosofi, visi dan misi serta kompetensi bidang layanan, 2) delivery system yang di dalamnya memuat kurikulum bimbingan, perencanaan individual, layanan responsif, dan dukungan sistem, 3) management system yang terdiri dari tata aturan, penggunaan data, rencana tindakan dan penjadwalan, serta : 4) accountability yang di dalamnya terkandung laporan hasil kinerja guru dan evaluasi program. Pada bidang akuntabilitas inilah pengembangan kompetensi guru bk menjadi sangat urgen.

Berbagai penelitian terhadap guru bk di sekolah menengah yang berada di bawah Kementrian Pendidikan dan Kebudayaan telah banyak dilakukan misalnya Nurrahmi (2015), Umari \& Yakub (2018), Hanifah (2017), Hajati (2012), dan Nurhudaya (2010). Akan tetapi, penelitian terhadap guru bk yang berada di bawah Kementrian Agama khususnya yang bertugas di madrasah tsanawiyah dan aliyah masih jarang ditemukan padahal madrasah memiliki potensi yang cukup besar dalam menyiapkan generasi yang akan memberikan kontribusi positif terhadap kemajuan bangsa dan negara.

Studi pendahuluan yang dilakukan oleh penulis (2019) terhadap 25 guru bimbingan dan konseling terkait dengan kompetensi pengelolaan layanan bimbingan di madrasah tsanawiyah dan aliyah di Kabupaten Garut diperoleh informasi bahwa kompetensi guru bk madrasah secara umum berada pada kategori kurang baik sebagaimana yang dapat dilihat pada tabel 1 . 
Vol 1. No. 4, Oktober 2021 P-ISSN : 2774-8030, e-ISSN : 2774-8030

Tabel 1. Studi Pendahuluan Profil Kompetensi Guru Bimbingan dan Konseling

\begin{tabular}{|l|c|c|c|}
\hline \multirow{2}{*}{\multicolumn{1}{c|}{ Aspek Kemampuan }} & \multicolumn{3}{|c|}{ Kategori } \\
\cline { 2 - 4 } & Sangat Baik & Baik & Kurang Baik \\
\hline Need Assesment & 48 & 24 & 28 \\
\hline Perencanaan Program & 20 & 36 & 44 \\
\hline Pelaksanaan Program & 16 & 52 & 32 \\
\hline Penilaian Program & 12 & 40 & 48 \\
\hline Laporan Kegiatan & 16 & 36 & 48 \\
\hline Tindak Lanjut Program & 8 & 36 & 56 \\
\hline Rata-rata & $\mathbf{2 0}$ & $\mathbf{3 7}$ & $\mathbf{4 3}$ \\
\hline
\end{tabular}

Hasil penelitian sebagaimana yang tercantum pada tabel 1 menginsyaratkna bahwa kompetensi guru bk madrasah masih belum menggembirakan terutama apabila mengacu pada Permendikbud Nomor 111 Tahun 2014. Idealnya mereka dapat menampilkan kompetensi yang cukup baik karena telah dibekali ilmu baik pada saat di LPTK maupun berbagai pelatihan yang berkaitan dengan pengembangan profesi bimbingan dan konseling serta pengalaman mereka dalam menjalankan tugas di madrasah tempat bekerja.

Gysbers, Norman and Henderson (2012) mengemukakan bahwa program bimbingan komprehensif merupakan bagian integral dari program pendidikan di sekolah yang dilaksanakan oleh guru bk dengan tujuan untuk memenuhi kebutuhan semua siswa dengan memfasilitasi pengembangan akademik, pribadi / sosial, dan karir serta membantu menciptakan iklim belajar yang positif. Pada saat yang bersamaan, program ini membantu siswa dalam menghadapi dan menyelesaikan masalah yang menjadi penghambat dalam tahapan perkembangannya.

Kompetensi dalam menyelenggarakan kegiatan bimbingan menjadi salah satu kompetensi yang harus dimiliki oleh guru bk. Cobia and Henderson (2003) dan Schmidt (2003) mengemukakan bahwa tugas guru bk di sekolah menengah adalah merencanakan, mengorganisasikan, melaksanakan dan melakukan evaluasi program. Dengan mengacu pada Permendikbud Nomor 27 Tahun 2008, kompetensi yang dimaksud dalam penelitian ini yaitu kemampuan guru bk dalam mengelola layanan bimbingan yang meliputi enam kegiatan yaitu : analisis kebutuhan, perencanaan program, pelaksanaan program, evaluasi program, laporan kegiatan, serta tindak lanjut pengembangan program.

Pada umumnya upaya yang dilakukan untuk mengatasi persoalan kompetensi adalah melalui pelatihan (Gomes, 2003). Berbagai penelitian terkait dengan peningkatan kompetensi guru bk telah dilakukan misalnya, Hajati (2010) membuat model program peningkatan kompetensi melalui pendekatan ADDIE, Heriyanti (2013) membuat program pelatihan dengan pendekatan induktif untuk meningkatkan kompetensi, Nurrahmi (2015) membuat model peningkatan kompetensi melalui pelatihan berdasarkan kompetensi, serta Nurhudaya (2012) membuat model pelatihan, workshop dan pendampingan.

Pelatihan pada hakikatnya adalah sebuah proses pembelajaran sehingga akan sangat efektif apabila mempertimbangan prinsip-prinsip pembelajaran. Merrill (2002) mengemukakan bahwa proses belajar akan berlangsung efektif apabila : 1) proses pembelajaran dihubungkan dalam upaya untuk memecahkan masalah, 2) adanya pengaktifan pengetahuan awal untuk memperoleh pengetahuan baru, 3) adanya demontrasi pengetahuan baru kepada peserta, 4) adanya aplikasi pengetahuan baru, dan 5) adanya integrasi pengetahuan baru kepada peserta. Kelima prinsip tersebut dikenal dengan istilah First Principles of Instruction.

First Principles of instruction dipilih sebagai sebuah pendekatan dalam pelatihan disebabkan karena pendekatan ini dapat memberikan dampak bagi para peserta. Studi Frick, Chadha, Watson, Wang, \& Green (2007) terkait dengan First Principles of Instruction dengan menyurvei 140 mahasiswa di 89 perguruan tinggi, menemukan bahwa pembelajaran melalui First Principles of Instruction menyebabkan mahasiswa sembilan kali lebih cepat dalam menguasai tujuan belajar. Studi Gardner (2011) mengamati pengajar pemenang penghargaan 
di sebuah perguruan tinggi dan menemukan bahwa mereka menggunakan First Principles of Instruction dalam pembelajarannya.

Studi Thomson (2002) membandingkan keefektifan pembelajaran menggunakan First Principles of Instruction dengan pengajaran tradisional dan menemukan bahwa siswa dalam kelompok belajar First Principles of Instruction secara signifikan lebih banyak dan lebih cepat dalam menyelesaikan tugas belajar. Studi lain menemukan bahwa siswa biologi yang belajar dengan menggunakan First Principles of Instruction telah meningkatkan kepercayaan diri mereka terhadap kemampuan mereka untuk memecahkan masalah di masa depan, dibandingkan dengan peserta didik lainnya (Gardner: 2011).

Selanjutnya, yang menjadi persoalan dalam penelitian adalah "Apakah pelatihan berbasis first principles of instruction" dapat meningkatkan kompetensi guru bk madrasah khususnya dalam mengelola layanan bimbingan dan konseling? Inilah yang sesungguhnya mendorong penulis untuk segera melakukan penelitian. Penelitian ini diarahkan pada program peningkatan kompetensi guru bk dalam mengelola layanan bimbingan dan konseling melalui pelatihan berbasis First Principles of Instruction.

\section{METODE PENELITIAN}

Penelitian menggunakan pendekatan kuantitatif melalui metode eksperimen kuasi. Peneliti memilih eksperimen kuase karena faktor biaya yang relatif lebih terjangkau dibandingkan penelitian yang sesungguhnya (true experiment), pemilihan responden secara acak seringkali sulit dilakukan; pertimbangan etis dalam memberikan perlakuan, ada hambatan dalam pengontrolan secara lengkap dan kesukaran dalam menentukan kelompok kontrol yang relevan (Heppner, Wampold and Kivligan, 2008: 182).

Penelitian menggunakan One Group Pretest-Posttest Design dengan cara secara acak memilih satu kelompok yang kemudian diberikan tes awal sebelum diberikannya perlakuan, atau pretes $\mathrm{O}_{1}$, lalu kelompok itu diberi perlakuan $(\mathrm{X})$, dan pasca pemberian perlakuan diberikan postes $\mathrm{O}_{2}$ (Sugiyono, 2008; Furqon, 2009; Ali, 2011; Noor, 2017; Mustafa, 2009; Arikunto, 2010). Desain penelitian dapat dilihat sebagaimana di bawah ini :

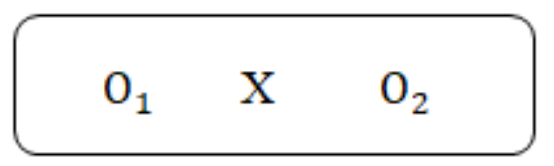

Penelitian dilaksanakan di Kabupaten Garut dalam kegiatan MGBK madrasah (tsanawiyah dan aliyah) dengan subjek penelitiannya adalah guru bimbingan dan konseling yang sudah ataupun belum tersertifikasi dan telah berpengalaman minimal 2 tahun. Dari 80 orang guru bimbingan dan konseling diambil 25 orang yang akan menjadi subjek penelitian. Subjek penelitian dapat dilihat pada lampiran.

Instrumen dalam penelitian ini yaitu tes dengan tujuan untuk melihat profil kompetensi Guru BK dalam mengelola layanan bimbingan dan konseling di madrasah yang berjumlah 40 butir soal berbentuk pilihan ganda. Instrumen ini dikembangkan oleh peneliti dengan merujuk pada Permendikbud Nomor 111 Tahun 2014 dan Permendikbud Nomor 27 Tahun 2008. Kisikisi instrument dapat dilihat pada lampiran.

Untuk mengetahui validitas instrument digunakan teknik korelasi item - total product moment. Sedangkan untuk mengetahui relialibilitas instrument digunakan Cronbach's Alpha $(\alpha)$ selanjutnya dihitung dengan bantuan Mc excel 2010. Hasil perhitungan menunjukkan bahwa dari 50 item soal, terdapat 40 soal yang dinyatakan valid dan relialibitas instrument sebesar 0.872 (Sangat Kuat) yang mengandung arti bahwa instrument ini layak untuk digunakan.

Penelitian untuk mengembangkan program peningkatan kompetensi guru bimbingan dan konseling melalui pelatihan berbasis first principles of instruction dilakukan melalui prosedur di bawah ini. 
1. Studi awal. Pada tahap ini penulis melakukan observasi ke beberapa madrasah juga kajian teori yang terkait dengan kompetensi guru bk dan pelatihan berbasis first principles of instruction.

2. Persiapan. Tahap ini penulis menyusun instrumen tes dan rumusan program pelatihan untuk meningkatkan kompetensi guru bimbingan dan konseling berbasis teori first principles of instruction.

3. Penimbangan instrumen. Penulis meminta bantuan 2 orang ahli untuk menimbang instrumen yang telah dikembangkan baik yang berasal dari akademisi ataupun yang berasal dari lapangan.

4. Uji coba instrumen. Uji coba ini mencakup uji validitas dan relialibilitas kepada beberapa guru bk. Penelaahan uji validitas dan relialibilitas instrumen dilakukan dengan penyortiran terhadap item instrumen yang tidak valid.

5. Revisi. Setelah penyortiran dilakukan, dilihat indikator kompetensi guru bk yang belum memiliki item valid kemudian disusunlah instrumen yang reliabel dan valid sehingga siap untuk digunakan dalam penelitian.

6. Eksperimen. Terhadap 25 bimbingan dan konseling madrasah diberikan pretest sebelum penelitian lalu diberi treatment berupa pelatihan berbasis first principles of instruction lalu di berikan post-test setelah selesai pelatihan.

7. Pengolahan data dan penyusunan laporan penelitian. Data tentang profil kompetensi konselor dan efektivitas pelatihan diolah dan selanjutnya disusunlah laporan hasil penelitian.

Ada dua data yang dihimpun dalam penelitian yaitu data tentang profil kompetensi guru bk dan uji efektivitas program pelatihan berbasis first principles of instruction. Untuk mengetahui profil kompetensi guru bk digunakan teknik persentase sementara itu, untuk pengujian efektivitas program menggunakan statistic non-parametric dengan uji wilcoxon yang selanjutnya dihitung dengan menggunakan SPSS 18.

\section{HASIL DAN PEMBAHASAN}

\section{Hasil Penelitian}

\section{Profile Kompetensi Guru Bimbingan dan Konseling Madrasah}

Hasil penelitian sebagaimana yang tampak pada Gambar 1 menunjukkan bahwa ratarata skor posttest kompetensi guru bimbingan dan konseling dalam mengelola layanan bimbingan dan konseling adalah 53,78. Angka tersebut jika dibandingkan dengan kriteria penafsiran menunjukkan bahwa kualifikasi kompetensi utuh pengelolaan layanan bimbingan dan konseling termasuk kategori sedang. Sementara itu, rata-rata skor pretest adalah 47,22. Angka rata-rata sebesar itu termasuk kualifikasi kurang.

Dilihat dari rata-rata skor setiap kompetensi pada saat posttest terlihat bahwa hanya satu kompetensi yang termasuk kategori cukup yaitu sub kompetensi evaluasi program; empat subkompetensi termasuk dalam kategori sedang yaitu sub- kompetensi analisis kebutuhan, perencanaan program, laporan program dan tindak lanjut program. Satu sub-kompetensi yang berada pada kategoti kurang yaitu pelaksanaan program. 


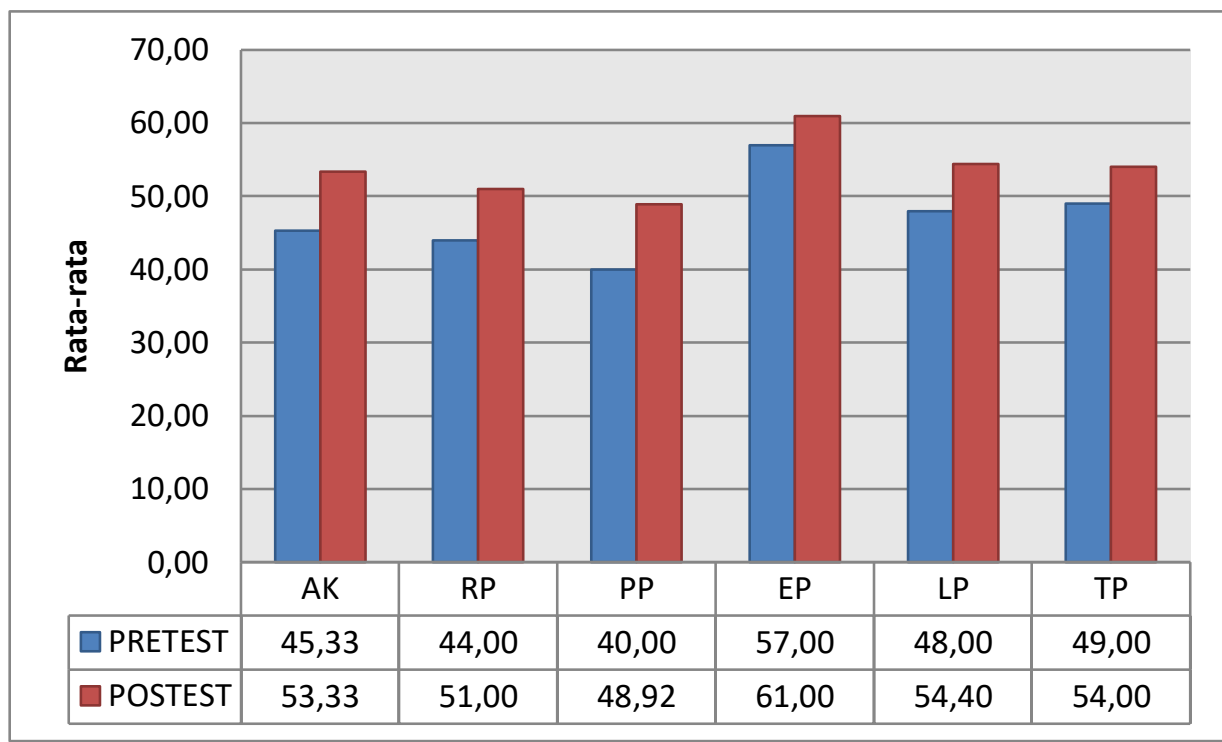

Gambar 1 Profile Kompetensi Guru Bimbingan dan Konseling Madrasah

Dilihat dari rata-rata skor setiap kompetensi pada saat pretest terlihat bahwa hanya satu kompetensi yang termasuk kategori sedang yaitu sub kompetensi evaluasi program; lima subkompetensi lainnya berada pada kategori kurang yaitu sub kompetensi analisis kebutuhan, perencanaan program, pelaksanaan program, laporan program dan tindak lanjut program.

\section{Keefektifan Program Pelatihan Berbasis First Principles of Instruction}

Dalam rangka menjawab pertanyaan penelitian nomor tiga, yaitu tentang efektivitas program penguatan kompetensi guru bimbingan dan konseling melalui Pelatihan berbasis First Principles of Instruction maka Uji efektivitas program secara empirik dilakukan dengan cara membandingkan rata-rata skor kompetensi utuh pengelolaan layanan bimbingan dan konseling sebelum dan sesudah pelatihan/ pretest dan posttest. Program dikatakan efektif apabila harga p-value $=0,000<0,05$ atau $\mathrm{H}_{0}$ ditolak. Dengan menggunakan SPSS diperoleh perhitungan sebagaimana yang terlihat pada tabel 1 berikut ini.

Tabel 1 Ranks Wilcoxon

\begin{tabular}{|l|l|r|r|r|}
\hline \multicolumn{2}{|c|}{} & $\mathrm{N}$ & Mean Rank & Sum of Ranks \\
\hline Postest - Pretest & Negative Ranks & $0^{\mathrm{a}}$ & .00 & .00 \\
\cline { 2 - 5 } & Positive Ranks & $25^{\mathrm{b}}$ & 13.00 & 325.00 \\
\cline { 2 - 5 } & Ties & $0^{\mathrm{c}}$ & & \\
\cline { 2 - 6 } & Total & 25 & & \\
\hline
\end{tabular}

a. Postest < Pretest

b. Postest $>$ Pretest

c. Postest $=$ Pretest

Test Statstic

\begin{tabular}{|l|r|}
\hline & \multicolumn{2}{|c|}{ Postest - Pretest } \\
\hline Z & $-4.396^{\mathrm{a}}$ \\
\hline Asymp. Sig. (2-tailed) & .000 \\
\hline
\end{tabular}

a. Based on negative ranks.

b. Wilcoxon Signed Ranks Test

Pada tabel rank, dapat disimpulkan bahwa jumlah rank negatif adalah 0 dan rank positif 325. Selanjutnya pada tabel Test Statistik, diperoleh harga $Z=-4,396$ dan $p$-palue $=0,000<0,05$ atau H0 ditolak. Dengan demikian dapat disimpulkan bahwa pelatihan berbasis first principles of instruction dapat menguatkan kompetensi guru bimbingan dan konseling Madrasah di Kabupaten Garut.

Apabila dilihat dari perkembangan kompetensi guru bimbingan dan konseling madrasah setelah diberikan pelatihan maka diperoleh data sebagaimana berikut ini. 
Tabel 2. Profil Umum Kompetensi Guru Bimbingan dan Konseling

\begin{tabular}{|c|l|c|c|c|}
\hline \multirow{2}{*}{ No } & \multirow{2}{*}{ Sub-Kompetensi } & \multicolumn{2}{|c|}{$\begin{array}{c}\text { Pencapaian Tingkat } \\
\text { Perkembangan }\end{array}$} & \multirow{2}{*}{ Peningkatan } \\
\cline { 3 - 4 } & & Pre Test & Post Test & \\
\hline 1 & Need Assesment & 45,53 & 53,33 & 8,00 \\
\hline 2 & Perencanaan Program & 52,00 & 59,00 & 7,20 \\
\hline 3 & Pelaksanaan Program & 42,12 & 49,96 & 7,84 \\
\hline 4 & Evaluasi Pelaksanaan Program & 57,00 & 61,00 & 4,00 \\
\hline 5 & Laporan Program & 46,50 & 53,00 & 6,50 \\
\hline \multirow{2}{*}{6} & $\begin{array}{l}\text { Tindak Lanjut Pengembangan } \\
\text { Program }\end{array}$ & 49,00 & 54,00 & 5,00 \\
\hline & Rata-Rata & $\mathbf{4 8 , 2 7}$ & $\mathbf{5 4 , 6 0}$ & $\mathbf{6 , 4 2}$ \\
\hline
\end{tabular}

Berdasarkan data pada tabel 2 terlihat perubahan skor kompetensi guru bimbingan dan konseling madrasah sebelum dan sesudah diberikan pelatihan bahwa pada umumnya meningkat 6,42. Sub kompetensi yang paling tinggi peningkatannya yaitu Need Assesment dengan ratarata peningkatan 8,00 , pelaksanaan program rata-rata peningkatan 7,84 , perencanaan program rata-rata peningkatan 7,20, laporan program rata-rata peningkatan 6,5 , tindak lanjut program rata-rata peningkatan 5,00, dan evaluasi program rata-rata peningkatan 4,00. Hal ini mengandung makna bahwa pelatihan berbasis First Principles of Instruction efektif dalam meningkatkan kompetensi guru bimbingan dan konseling pada setiap aspek dan indikatornya.

\section{Pembahasan Penelitian}

\section{Profil Kompetensi Guru Bimbingan dan Konseling Madrasah}

Hasil pengolahan data menginsyaratkan bahwa hampir semua indikator yang terdapat pada variabel kompetensi guru bimbingan dan konseling madrasah termasuk pada kategori kurang dengan rata-rata 48,27. Indikator kompetensi yang tampak paling tinggi apabila dikomparasikan dengan indikator lainnya adalah pada kompetensi evaluasi program bimbingan dan konseling dengan skor 57,00 termauk pada kategori sedang. Adapun indikator yang tampak relatif rendah dibandingkan dengan indikator-indikator lain dalam variabel kompetensi pengelolaan layanan bimbingan dan konseling adalah indikator implementasi program bimbingan dengan skor 42,12 termasuk pada kategori kurang.

Hal ini mengisyaratkan bahwa pada umumnya guru bimbingan dan konseling madrasah di Kabupaten Garut masih belum mempunyai kompetensi yang cukup baik dalam mengelola kegiatan bimbingan dan konseling yang meliputi kemampuan dalam melakukan need asessment, menyusun perencanaan program, melaksanakan program, melakukan evaluasi program, membuat laporan kegiatan dan follow up/ tindak lanjut pengembangan program. Hal ini disebabkan oleh karena pengetahuan dan keterampilan yang dimiliki oleh guru bimbingan dan konseling madrasah masih kurang khususnya terkait dengan bidang pekerjaan pokoknya yaitu penyelenggaraan kegiatan bimbingan dan konseling.

Hasil penelitian ini sesuai dengan penelitian Hajati (2012) yang mengemukakan bahwa kompetensi penguasaan teori yang ada pada konselor, dan keterlaksanaan pelayanan bimbingan di SMA Negeri rayon $X$ khususnya terkait dengan kemampuan dalam merencanakan dan melaksanakan program mengindikasikan bahwa : 1) pada umumnya konselor kurang mempunyai sikap, nilai, dan kepribadian yang mendukung, 2) kebanyakan konselor memiliki skill yang lemah dalam mengenal secara mendalam siswa yang akan dilayani, 3) pada umumnya konselor belum dapat menguasai kerangka teoretik bimbingan dan konseling; rerata sangat kurang dalam penguasaan teori, prinsip, dan prosedur bimbingan dan konseling, dan 4) rerata konselor belum dapat menyelenggarakan layanan bimbingan yang memandirikan atau dengan kata lain beberapa kegiatan yang telah direncanakan tidak dapat dilaksanakan dengan baik. 
Penelitian ini juga senada dengan penelitian Umari (2008) yang mengemukakan bahwa $50 \%$ dari guru bimbingan dan konselilng di sekolah mempunyai kemampuan dalam pengumpulan data, penyusunan program, implementasi layanan BK, evaluasi kegiatan $\mathrm{BK}$, penerapan etika profesional BK, serta dalam pelaksanaan penelitian. Akan tetapi hasil penelitian berbeda dengan penelitian Nurrahmi (2015) yang menyatakan bahwa sebagian besar guru bimbingan dan konseling SMK memiliki kompetensi dalam menjalankan tugas keprofesionalannyanya. Hal ini dapat difahami bahwa pada umumnya sekolah-sekolah yang berada di bawah kemendikbud dalam hal ini SMP, SMA dan SMK kualifikasi guru bimbingan dan konselilng memiliki riwayat yang lebih lama jika dibandingkan dengan sekolah-sekolah yang diselenggarakan di bawah Kementrian Agama dalam hal ini MTs dan MA.

Apabila dilihat dari latar belakang pendidikan penelitian ini juga menemukan bahwa dari 25 guru bimbingan dan konseling yang menjadi subjek penelitian terdapat 32,00\% yang berlatar belakang sesuai dengan bidang keilmuannya sementara itu 68,00 yang tidak sesuai. Hal ini menunjukkan bahwa adalah sebuah keniscayaan untuk dapat bekerja dengan professional maka siapapun harus melewati proses pendidikan yang professional. Peneltian ini membuktikan bahwa mereka yang tidak melewati pendidikan akan terkendala dengan penguasaan kompetensi dalam pekerjaannya. Pitaloka (2018), Fadiarman (2018), Mutakin (2015) mengemukakan bahwa terdapat hubungan yang positif antara latar belakang pendidikan dengan kompetensi. Artinya, semakin seseorang memiliki latar belakang pendidikan yang sesuai dengan bidang keilmuannya maka akan semakin meningkat pula kompetensi dalam menjalankan tugasnya.

Apabila dilihat dalam pandangan Standar Nasional Pendidikan, tampak bahwa Standar Kompetensi Lulusan yang seharusnya memiliki kualifikasi kemampuan lulusan yang cukup baik dalam pekerjaannya dalam hal ini kompetensi guru bimbingan dan konseling menunjukkan pada level belum cukup baik. Standar kompetensi lulusan akan sangat berkaitan dengan standar proses. Oleh karenanya penelitian ini juga dapat berkontribusi pada LPTK untuk lebih memperhatikan standar proses dalam penyelenggaraan pendidikan khususnya bagi calon guru bimbingan dan konseling dalam menguasai keterampilan dalam mengelola layanan bimbingan dan konseling yang meliputi perencanaan sampai tindak lanjut pengembangan program bimbingan dan konseling.

\section{Kefektifan Program Pelatihan berbasis First Principles Of Instruction}

Program pelatihan berbasis first principles of instruction dirancang untuk meningkatkan kompetensi guru bimbingan dan konselilng dalam mengelola layanan bimbingan dan konseling di madrasah. Kefektivan program di uji dengan membandingkan skor pretest (sebelum pelatihan diberikan) dan postest (setelah pelatihan diberikan) yang menunjukkan bahwa terdapat perbedaan skor responden baik sebelum ataupun sesudah dilakukannya pelatihan. Hal ini menunjukkkan bahwa program Pelatihan berbasis first principles of instruction efektif dalam meningkatkan kompetensi guru bimbingan dan konseling dalam mengelola layanan bimbingan dan konseling di madrasah.

Hipotesis yang akan diuji dalam penelitian adalah progam pelatihan berbasis first principles of instruction efektif dalam meningkatkan kompetensi konselor madrasah. Secara keseluruhan program Pelatihan berbasis First Principles of Instrustion terbukti dapat menguatkan kompetensi guru bimbingan dan konseling secara signifikan. Hal ini mengandung arti bahwa apabila program pelatihan berbasis first principles of instruction dilaksanakan sesuai dengan panduan yang telah dibuat maka kompetensi guru bimbingan dan konseling dalam mengelola layanan bimbingan dan konseling akan meningkat. Perubahan signifikan ini dapat terlihat pada persentase peningkatan kompetensi guru bimbingan dan konseling yang secara keseluruhan meningkat sebanyak 6,42. Terjadi peningkatan keseluruhan kompetensi guru bimbingan dan konseling dari 48,27 sebelum pelatihan menjadi 54,60 setelah pelatihan berbasis first principles of instruction.

Pelatihan berbasis First Principles of Instruction dipandang efektif dalam menguatkan kompetensi guru bimbingan dan konselilng madrasah karena beberapa alasan, yaitu : 
Petama, Pelatihan berbasis First Principles of Instruction sangat memperhatikan konten dalam pembelajaran. Merrill (2013) mengemukakan bahwa komponen utama dari strategi pembelajaran adalah materi yang akan diajarkan yang meliputi pengetahuan dan keterampilan yang diperlukan untuk menyelesaikan suatu masalah/ tugas yang sangat kompleks. Terdapat lima tipe Materi dalam pelatihan berbasis First Principles of Instruction yaitu : 1) Informational-about merupakan kemampuan peserta dalam mengingat materi yang berkaitan dengan suatu objek, aktivitas atau proses yang spesifik, 2) Part-of adalah kemampuan peserta untuk menempatkan, menamai dan mendeskripsikan suatu objek, peristiwa atau proses, 3) Kind-of adalah kemampuan peserta dalam mengidentifikasi bagian dari objek, peristiwa dan proses yang memiliki karakteristik umum atau yang disebur dengan konsep tertentu, 4) Howto merupakan keterampilan peserta dalam melakukan langkah-langkah atau prosedur secara berurutan dan 5) What-Happens merupakan kemampuan peserta untuk memprediksi konsekuensi dari serangkaian kondisi atau menemukan kondisi yang tidak memadai atau untuk menemukan konsekuensi tidak terduga. Dalam hal ini materi yang disajikan adalah yang berkaitan dengan pengelolaan layanan bimbingan dan konseling.

Kedua, pelatihan berbasis First Principles of Instruction sangat memperhatikan interkasi dalam pembelajaran. Merrill (2013) menegaskan bahwa interaksi dalam pembelajaran merupakan komponen pembelajaran penyebab terjadinya peristiwa pembelajaran yang meliputi empat mode/ gaya penyajian yaitu terdiri atas : Tell, Ask, Show dan Do. Tell merupakan interaksi pembelajaran dimana fasilitator menyampaikan materi pembelajaran. Ask merupakan interaksi pembelajaran dimana peserta diminta untuk mengingat kembali informasi yang sudah disampaikan. Show merupakan interaksi pembelajaran dimana fasilitator menunjukkan/ mendemonstrasikan suatu aktivitas kepada peserta. Do merupakan interkasi pembelajaran dimana peserta diminta untuk mengaplikasikan informasi dalam situasi/ aktivitas khusus. Secara lebih spesifik pelatihan ini menekankan pada Tell and Show Instructional dimana peserta dapat berinteraksi sebagaimana yang terjadi dalam keseharian. Peserta difasilitasi untuk mengambil langkah/ melaksanakan berbagai aktifitas pembelajaran kemudian diberi respon. Jika benar, diberi penguatan dan jika keliru maka akan diberi masukan dan diarahkan untuk mencobanya kembali.

Ketiga, pelatihan berbasis First Principles of Instruction, memperhatikan strategi pembelajaran yang sesuai dengan kemampuan yang diperlukan. Merrill (2013) menerangkan ada empat tahapan strategi pembelajaran yang dilakukan dalam pembelajaran yaitu tahap Presentation, Practice, Demonstration, dan Application. Presentation mengandung makna bahwa fasilitator menceritakan terjadinya peristiwa pembelajaran. Practice mengandung arti bahwa fasilitator meminta umpan balik yang sesuai dalam peristiwa pembelajaran. Demonstation mengandung makna bahwa fasilitator menunjukkan peristiwa pembelajaran melalui proses bimbingan. Terkahir, Application yang mengandung arti bahwa fasilitator meminta peserta untuk mengalami pembelajaran dengan melakukan suatu kegiatan yang dibarengi dengan coaching serta masukan yang sesuai. Selanjutnya strategi pembelajaran juga melibatkan unsur Mnemonic atau bantuan memori untuk membantu pelajar mengingat informasi penting.

Keempat, Pelatihan berbasis First Principles of Instruction, mengupayakan strategi pembelajaran yang berorientasi untuk menyelesaikan masalah dalam keseharian. Merrill (2013) mengemukakan bahwa pembelajaran akan terjadi meningkat pada saat peserta didik memperoleh pengetahuan dan keterampilan yang berkaitan dengan pemecahan masalahmasalah dalam kehidupan nyata. Implementasi prinsip ini memerlukan dua desain pembelajaran yaitu : mengidentifikasi elemen-elemen konten dari masalah dan merancang strategi pembelajaran untuk mengajarkan konten tersebut. Elemen konten untuk seluruh masalah terdiri dari urutan peristiwa pemecahan masalah, masing-masing terdiri dari langkah yang mengarah ke suatu kondisi dan di mana kondisi tersebut diperlukan untuk membawa pada konsekuensi. Strategi pembelajaran dilakukan melalui : 1) Demonstrasi seluruh masalah yaitu melakukan demonstrasi konsekuensi, kondisi, dan langkah-langkahnya; 2) Demonstrasi dengan 
menceritakan atau menunjukkan (Tell/ Show) langkah dan kondisi untuk masing-masing peristiwa pemecahan masalah; 3) Melakukan kegiatan untuk memprediksi konsekuensinya dan menemukan kondisi yang salah, dan / atau mengeksekusi semua langkah dari seluruh masalah.

Kelima, Pelatihan berbasis First Principles of Instruction, mengupayakan strategi pembelajaran yang berorientasi pada masalah. Merrill (2013) menyatakan bahwa belajar akan meningkat apabila peserta didik terlibat dalam pembelajaran yang berpusat pada masalah yang disajikan dalam konsteks persoalan/ tugas yang sederhana sampai kepada masalah yang kompleks dalam kehidupan sehari-hari. Oleh karenanya, langkah-langkah dalam strategi pembelajaran yang berpusat pada masalah meliputi : 1) Identifikasi progres perkembangan masalah, 2) Presentasi penggambaran masalah pertama, 3) Tell/ Show keterampilan untuk penggambaran masalah pertama, 4) Menyajikan penggambaran masalah kedua, 5) Meminta peserta menerapkan (Do) keterampilan untuk penggambaran masalah kedua, 6) Tell and Show elemen kemampuan penggambaran masalah kedua, 7) Mengulangi tahap 4, 5, dan 6 untuk masalah berikutnya sampai diimplementasikannya semua elemen keterampilan, 8) Meminta peserta menerapkan (Do) semua keterampilan ke penggambaran masalah akhir.

Keenam, Pelatihan berbasis First Principles of Instruction, meningkatkan strategi pembelajaran dengan kerangka pikir yang terstruktur dan interaksi sesama peserta. Merrill (2013) mengemukakan bahwa kerangka struktural merupakan organisasi informasi yang dimiliki oleh peserta sebelum dilakukan proses pembelajaran yang kemudian digunakan oleh peserta untuk mengadaptasi model mental yang ada atau untuk membangun model mental baru untuk suatu konten baru. Selain itu fasilitator juga mempresentasikan dan menggunakan kerangka pikir bimbingan selama proses demonstrasi, coaching selama proses aplikasi dan refleksi selama proses integrasi. Selain kerangka pikir terstruktur, pelatihan berbasis First Principles of Instruction juga memperhatikan interaksi di antara sesama peserta yang meliputi Peer Telling, Peer Sharing, Peer Discussion, Peer Collaboration dan Peer Critique.

Peer-Telling adalah suatu bentuk interaksi peserta yang kurang efektif di mana peserta mengulas dan menyajikan informasi kepada peserta lain. Peer-Sharing yaitu peristiwa pembelajaran di mana peserta berbagi pengalaman sebelumnya satu sama lain yang relevan dengan konten subjek yang sedang dipelajari. Peer-Discussion yaitu suatu bentuk interaksi peserta untuk saling mempertimbangkan solusi yang diusulkan terhadap suatu permasalahan. Peer-Collaboration yaitu suatu bentuk interaksi peserta pada saat bekerja sama di dalam kelompok terbatas untuk memecahkan masalah. Peer-Critique yaitu suatu bentuk interaksi peserta untuk saling mengevaluasi kegiatan pemecahan masalah dan memberikan saran yang konstruktif untuk peningkatan kemampuan masing-masing di kemudian hari.

Ketujuh, Pelatihan berbasis First Principles of Instruction, menggunakan multimedia dalam strategi pembelajaran. Merrill (2013) mengemukakan bahwa pembelajaran akan meningkat ketika multimedia diimplementasikan sesuai dengan peristiwa dan fungsi pembelajaran. Hal-hal yang perlu dipersiapkan dalam tayangan multimedia yaitu : 1) tombol navigasi yang terkait dengan konten berikutnya yang mengharuskan peserta untuk membuat keputusan tentang apa yang akan dilihat, dipelajari, atau ditinjau selanjutnya, 2) hati-hati dengan multimedia yang menarik tetapi tidak memiliki fungsi pembelajaran sehingga dapat mengganggu proses pembelajaran, 3) hati-hati dengan penggunaan animasi yang tidak berfungsi untuk mendukung proses pembelajaran, 4) hati-hati dalam penggunaan teks berwarna, latar belakang, dan dekorasi yang menarik tetapi tidak mendukung pada proses pembelajaran, 5) penggunaan tombol yang memungkinkan peserta untuk memilih konten untuk dipelajari; kontrol audio, video, dan animasi; dan untuk mengontrol kegiatan pembelajaran lainnya dan 6) kesesuaian tampilan teks atau item grafik dengan elaborasi audio.

Dengan demikian, ketujuh alasan tersebut menjadi argumentasi terhadap efektifnya pelatihan berbasis First Principles of Instruction dalam Meningkatkan Kompetensi guru bimbigan dan konseling dalam mengelola layanan bimbingan dan konseling di Madrasah yang ada di Kabupaten Garut. 
Secara keseluruhan hasil penelitian menemukan bahwa program pelatihan berbasis first principles of instruction dapat meningkatkan kompetensi guru bimbingan dan konseling dalam mengelola layanan bimbingan dan konseling di madrasah. Sub kompetensi yang paling tinggi peningkatannya adalah pada kompetensi dalam melakukan need assessment dan yang terendah peningkatannya adalah pada sub kompetensi evaluasi pelaksanaan program bimbingan dan konseling. Hal ini yang sesungguhnya menjadi pembeda dari penelitian-penelitian sebelumnya. Sebagaimana yang telah disampaikan pada bagian awal tulisan ini bahwa pendekatan first principles of instruction dapat meningkatkan kompetensi belajar siswa dan mahasiswa (Frick at all, 2007). Studi Gardner (2011) menemukan bahwa instruktur pemenang penghargaan di sebuah perguruan tinggi adalah mereka menggunakan First Principles of Instruction dalam pembelajarannya serta pendekatan first principles of instruction dapat meningkatkan kepercayaan diri siswa biologi dalam memecahkan masalah. Studi Thomson (2002) menemukan bahwa pendekatan first principles of instruction lebih efektif daripada pembelajaran dengan pendekatan tradisional. Pada penelitian ini, sebagai sebuah kontribusi dan kebaruan dalam cakrawala ilmu pengetahuan menemukan bahwa pelatihan dengan pendekatan first principles of instruction dapat meningkatkan kompetensi guru bimbingan dan konseling pada keseluruhan sub kompetensi pengelolaan layanan bimbingan dan konseling di madrasah.

\section{KESIMPULAN}

Berdasarkan hasil dan pembahasan pada akhirnya dapat disimpulkan beberapa hal sebagaimana berikut ini.

Pertama, secara umum profil kompetensi guru bimbingan dan konseling madrasah dalam menyelenggarakan layanan bimbingan dan konseling berada pada kategori sedang. Hal ini mengandung arti bahwa guru bimbingan dan konseling belum memiliki kompetensi yang cukup baik dalam mengelola layanan bimbingan dan konseling di madrasah di Kabupaten Garut. Sub kompetensi yang paling rendah yaitu pada pelaksanaan program dan yang paling tinggi yaitu pada evaluasi pelaksanaan program.

Kedua, secara empirik program pelatihan berbasis First Prinsiciples of Instruction terbukti efektif dalam meningkatkan kompetensi guru bimbingan dan konseling madrasah dalam mengelola layanan bimbingan dan konseling. Pelatihan berbasis first principles of instruction dapat meningkatkan semua subkompetensi pengelolaan layanan bimbingan dan konseling. Sub kompetensi yang paling tinggi peningkatannya terletak pada sub kompetensi dalam melakukan need assesmen sedangkan peningkatan sub kompetensi yang paling rendah adalah pada sub kompetensi evaluasi pelaksanaan program.

\section{DAFTAR PUSTAKA}

American School Caounselor Association. (2012). The ASCA National Model : A Freamwork for School Counseling Program Third Edition, Third Edition. Alexandria, VA: Author.

Ali, M. (2011). Memahami Riset Prilaku dan Sosial. CV Pustaka Cendikia Utama.

Arikunto, S. (2010). Prosedur Penelitian: Suatu Pendekatan Praktik. PT Rineka Cipta.

Arman, E. A. (2018). Pengaruh Kompetensi, Motivasi Dan Pengembagan Karir Terhadap Kinerja Karyawan (Studi Kasus Pt. Royal Korindah Bumiayu) (Doctoral Dissertation, Universitas Muhammadiyah Purwokerto).

Cobia, D. C. (2003). Handbook of School Counseling (A. Crisp (ed.)). Pearson Educational.

Frick, T., Chadha, R., Watson, C., Wang, Y., \& Green, P. (2007). Theory-based course evaluation: Nine Scales for measuring teaching and learning quality. Retrieved from http://www.indiana.edu/ tedfrick/TALQ.pd

Furqon. (2009). Statistika Terapan untuk Penelitian. CV Alfabeta.

Gardner, J., (2011). How Award-winning Professors in Higher Education Use Merrill's First Principles of Instruction. International Journal of Instructional Technology and Distance Learning, 8(5), p. 3-16)

Gardner, Joel. Testing the Efficacy of Merrill's First Principles of Instruction in Improving 
Student Performance in Introductory Biology Courses. Diss. Utah State University, 2011

Gomes, F. C. (2003). Manajemen Sumber Daya Manusia. CV Andi Offset.

Gysbers, Norman C. (2012). Developing and Managing Your School Guidance and Counseling. USA : American Counseling Association.

Hajati, K. (2010). Model Program Peningkatan Kompetensi Konselor Berbasis Standar Kompetensi Konselor Indonesia. Universitas Pendidikan Indonesia.

Hajati, K. (2012). Kompetensi Konselor Indonesia (Studi Berdasarkan Profil Diskrepansi Kompetensi Aktual Dengan Kompetensi Standar Pada Konselor Sma Negeri Di Wilayah X ). Jurnal Bimbingan Dan Konseling, 20-32. Journal.Unj.Ac.Id

Hanifah, U. (2017). Kompetensi Profesional Guru Bk Dalam Implementasi Asessmen Bk Pada Guru Bk Di SMA Favorit Kota Banda Aceh. Jurnal Suloh: Jurnal Bimbingan Konseling Fkip Unsyiah, 2(1).

Hasanati, N. (2015). Pengaruh Motivasi Berprestasi terhadap Komitmen Profesi dan Kompetensi serta Dampaknya pada Kinerja Dosen Tetap UMM. PPS Universitas Padjadjaran Bandung.

Heriyanti. (2013). Program Pelatihan dengan Mengggunakan Pendekatan Induktif untuk Meningkatkan Kompetensi Konselor. Universitas Penndidikan Indonesia.

Heppner.P.P, Wampold. B.E \& Kivlighan. D. M. (2008). Research Design in Counseling. (edisi ketiga). Belmont, USA: Thomson Brooks/Cole.

Manik, S., \& Syafrina, N. (2018). Pengaruh Kompetensi Terhadap Kinerja Dosen Sekolah Tinggi Ilmu Ekonomi Riau. Jurnal Ilmiah Ekonomi Dan Bisnis (Jieb), 15(1), 16.

Merrill, D. (2002). First Principles of Instruction. Journal Educational Technology Reseach and Development, 50(3), 43-59.

Merrill, D. M. (2013). First Principles Of Instruction: Identifying and Designing Effective, Efficient, and Engaging Instruction (Rebecca Taff (ed.)). Pfeiffer An Imprint of Wiley.

Mustafa, Z. (2009). Mengurai Variabel Hingga Instrumen. Graha Ilmu.

Mutakin, T. Z. (2015). Pengaruh Kompetensi, Kompensasi, dan Latar Belakang Terhadap Kinerja Guru. Formatif: Jurnal Ilmiah Pendidikan MIPA, 3(2).

Noor, J. (2017). Metodologi Peneitian : Skripsi, Tesis, Disertasi dan Karya Ilmiah. Kencana Prenada Media Group.

Nurhudaya. (2012). Model Penguatan Kompetensi Konselor Dalam Bidang Asesmen Di Sekolah. Universitas Pendidikan Indonesia.

Nurrahmi, H. (2015b). Model Pelatihan Berbasis Kompetensi Untuk Meningkatkan Kompetensi Profesional Guru Bimbingan Dan Konseling Di Smk Se-Kota Pontianak. Universitas Pendidikan Indonesia.

Nurrahmi, H. (2015). Kompetensi Profesional Guru Bimbingan Dan Konseling. Jurnal Dakwah Alhikmah, 9(1), 45-55.

Permendikbud Nomor 111. (2014). Bimbingan dan Konseling pada Pendidikan Dasar dan Menengah.

Permendikbud Nomor 27. (2008). Standar Kualifikasi Akademik dan Kompetensi Konselor. 1 9

Pitaloka, D. L. (2018). Hubungan Latar Belakang Pendidikan dan Pengalaman Mengajar dengan Kompetensi Profesional Guru Tk. Pendidikan Guru PAUD S-1, 7(4), 348-355.

Saputra, I. P. A., Bagia, I. W., Si, M., \& Suwendra, I. W. (2016). Pengaruh Kompetensi Dan Disiplin Kerja Terhadap Kinerja Karyawan. Jurnal Manajemen Indonesia, 4(1).

Schmidt, J. J. (2003). Counseling in Schools : Essential Services and Comprehensive Programs. Pearson Educational.

Sriwidodo, U., \& Haryanto, A. B. (2010). Pengaruh Kompetensi, Motivasi, Komunikasi Dan Kesejahteraan Terhadap Kinerja Pegawai Dinas Pendidikan. Jurnal Manajemen Sumber Daya Manusia, 4(1), 47-57. 
Setiawati, T. (2009). Pengaruh Kompetensi Kerja Terhadap Kinerja Dosen. Media Pendidikan, Gizi, Dan Kuliner, 1(1).

Sugiyono. (2008). Metode Penelitian Pendidikan Pendekatan Kuantitatif, Kualitatif dan R and D. CV Alfabeta.

Thomson. (2002). Thomson job impact study: The next generation of learning [electronic version] Retrieved

from http://www.delmarlearning.com/ resources/job_impact_study_whitepaper.pdf Archived 2010-08-27 at the Wayback Machine

Umari, T., \& Yakub, E. Analisis Kompetensi Profesional Guru Bimbingan Dan Konseling Di Sekolah. Pelita Bangsa Pelestari Pancasila, 13(2), 135-145. 